DOI: https://doi.org/10.24867/14GI14Djuric

\title{
RAZVOJ TALENATA KAO KLJUČNI FAKTOR STVARANJA KONKURENTSKE PREDNOSTI
}

\section{TALENT DEVELOPMENT AS A KEY FACTOR IN CREATING COMPETITIVE ADVANTAGE}

\author{
Marija Đurić, Fakultet tehničkih nauka, Novi Sad
}

\section{Oblast - INDUSTRIJSKO INŽENJERSTVO I INŽENJERSKI MENADŽMENT}

Kratak sadržaj - Rad je posvećen analizi talenata $u$ organizaciji, njihovom pronalaženju, razvoju, zadržavanju i upravljanju njima. Talenti su istraživani kroz proces aktivnosti sektora za ljudske resurse.

Istraživanje je sprovedeno u proizvodnom preduzeću kojim su obuhvaćena četiri sektora. Dobijeni rezultati ukazuju da su talenti ključan faktor stvaranja konkurentske prednosti.

Ključne reči: Talenti, konkurentska prednost, razvoj, ključan faktor

Abstract - The paper dedicated to the anaiysis of talents in organization, it's finding, development, retention and management of talents. Talents were explored through the process of the human resorce sector.

The research was conducted in a manufacturing company covering four sectors. Based on the obtained results it is confirmed that talents are a key factor in creating a competitive advantage of an organization.

Keywords: Talent, copmetition advantage, development, a key factor

\section{UVOD}

Upravljanje talentima definiše se kao proces kojim poslodavci predviđaju i ispunjavaju svoje potrebe za ljudskim resursima. Osnovna težnja i izazov svake savremene organizacije je da prave ljude sa pravim veštinama postavi na pravo mesto, što ujedno predstavlja i opštu definiciju menadžmenta talentima.

Tokom poslednjih godina stručnjaci iz raznih oblasti uvideli su da je kvalitetno upravljanje talentima izuzetno važno za produktivnost i motivaciju zaposlenih. Međutim, ono čemu se nije pridavala velika važnost jeste razvijanje strategije upravljanja talentima kao i usaglašavanje strategije razvoja talent menadžmenta sa organizacionim ciljevima.

U savremenim organizacijama talentovani pojednici postaju strategijski resurs čije angažovanje dovodi do izvrsnosti organizacionih performansi. Upravljanje talentima je od vitalnog značaja i za pojedince i za organizaciju. Pojedinci, kojima je omogućeno da iskažu svoj potencijal, generišu inovacije i doprinose pozitivnim

\section{NAPOMENA:}

Ovaj rad proistekao je iz master rada čiji mentor je bila dr Ivana Katić, vanr. prof. promenama $\mathrm{u}$ organizaciji, a istovremeno su zadovoljniji jer uspevaju da se samoaktualizuju i da napreduju. Menadžeri koji rukovode talentima doprinose povećavanju produktivnosti, a time i jačanju konkurentske pozicije organizacije u tržišnim uslovima poslovanja.

\section{POJAM TALENTA}

Jedno od značenja reči talenat jeste da predstavlja mentalne sposobnosti osobe. Ovo tumačenje je osnova za posmatranje talenta kao urođenog dara ili prirodne sposobnosti, koji obuhvata lične osobine koje ga čine efikasnim u odnosu na druge vršnjake. Osim ovoga, postoji i posmatranje talenta kroz posvećenost, usmeravanje fokusa i pažnje koje se mere istrajnošću. Ako se talenat posmatra kao visok potencijal to znači da postoje sposobnosti ili mogućnosti da se razviju još neformirane strukture i postanu stvarne. To podrazumeva da pojedinac ima kvalitete (motivaciju, karakteristike, veštine, sposobnosti i iskustva, napreduju brže od svojih vršnjaka), ali su potrebni dalji rast i razvoj kako bi se postigao željeni cilj.

U kontekstu ljudskih resusa talenat se posmatra kao kapital ljudskih resursa, a pretvaranje talenata zaposlenih u efikasnu radnu snagu je ključni zadatak menadžmenta preduzeća. Upravljanje talentima predstavlja sistematičan i dinamičan proces kojima se ljudski resursi identifikuju, kako bi popunili ključne poslovne pozicije u budućnosti, spremaju se za širok spektar programa edukacije i obuke, vodi se računa o njihovoj daljoj promociji, zadržavanju i usmeravanju njihovih talenata kako bi postigli očekivane rezultate.

Dakle, organizacije su postale svesne da su talentovani ljudski resursi dragoceni resurs ukoliko se sa njima strateški upravlja. Svaka organizacija treba da ima odgovarajuće prakse talent menadžmenta zasnovane na sopstvenim vrednostima i ciljevima, a ne da dolazi u sitaciju da pokušava da usvaja i ponavlja uspešne prakse koje su koristile druge organizacije. Stoga se kaže da upravljanje talent menadžmentom treba da se rukovodi „,najboljim pristupom“, a ne „najboljom praksom“.

\section{TALENTI U LJUDSKIM RESURSIMA}

Značajna uloga ljudskih resursa jeste da identifikuje talente kako bi maksimizirali strateške mogućnosti u budućnosti. Ono što je važno naglasiti jeste neophodnost da se navedene sposobnosti organizacije integrišu sa 
organizacionom poslovnom strategijom i zajedno ugrade u poslovne procese.

Imperativi talent menadžmenta:

- Talenat kao suštinsko pitanje svake poslovne strategije: podrazumeva potrebu shvatanja vrednosti talenata, prepoznavanje ključnih komponenti poslovnih strategija koje se odnose na talente, kao i njihove implikacije na organizacione performanse.

- Različitost kao najveća vrednost organizacije: ključna konkurentska prednost organizacije zasniva se na sposobnosti organizacije da privuče, a njenih zaposlenih da rade sa različitim i raznovrsnim talentima.

- Učenje i razvoj veština kao najvažnije sposobnosti: usredsređivanje na jasno razumevanje specifičnih $i$ jedinstvenih veština $i$ kompetencija vodi ka uspehu.

- Pravilno angažovanje kao transformacija poslovnih rezultata: privlačenjem i motivisanjem zaposlenih omogućiće se uvećavanje talenata u organizaciji i poboljšanje njenih poslovnih rezultata.

- Obuka i razvoj talenata kao briga organizacije: menadžment ljudskih resursa ima ključnu ulogu po ovom pitanju, ali najbolja praksa i kultura okrenuta ka talentima treba da budu ugrađene $u$ celokupno poslovanje organizacije.

Dolazi se do zaključka da neophodnost odgovora na promenljivo okruženje ekonomije znanja, globalizaciju, znanje i radnike znanja kao osnove postizanja i održavanja konkurentske prednosti, nameće potrebu izmene funkcije menadžmenta ljudskih resursa u pravcu formulisanja poslovne strategije koja će $u$ centar interesovanja staviti talentovane, inovativne i kreativne zaposlene.

Ključna komponenta talent menadžment sistema je implementacija sistema selekcije koji se zasnivaju na strateškim kompetencijama organizacije i koriste se za eksternu i internu selekciju.

Obučavanje menadžera za vođenje intervjua koji se baziraju na ponašanju je veoma važan korak u razumevanju talent menadžmenta. Ako menadžeri mogu da savladaju tehniku procene talenata u toku selekcije, oni će takođe koristiti ove veštine prilikom ocenjivanja razvoja i potencijala njihovih zaposlenih.

\section{ZADRŽAVANJE TALENATA KAO ČINILAC DUGOROČNE USPEŠNOSTI POSLOVANJA ORGANIZACIJE}

Ljudski kapital danas zaista počinje da ima sve veću ulogu u poslovanju organizacija, zato upravo taj kapital zadržava bitne ljudske osobine poput znanja, veština, kreativnosti, iskustva, motivacije i sposobnosti, čijom se kombinacijom i kvalitetnim upravljanjem može stvoriti produktivnije poslovanje.

Osim toga ljudski kapital smatra se rezultatom napora $\mathrm{i}$ aktivnosti ljudi i menadžmenta ljudskim potencijalima koji se očitava u znanjima, veštinama, kompetencijama, motivaciji i odanosti zaposlenih.
Ulaganje u zadržavanje talenata uz inovacije menadžmenta ljudskih potencijala smatra se jednim od bitnijih aktivnosti celokupnog poslovanja određene organizacije. Naglasak takođe treba staviti na ulogu menadžera u zadržavanju talenata, a to se može uraditi na neki od sledećih načina:

- biranje na osnovi talenta (nije poželjno odabrati samo na osnovu iskustva, inteligencije ili odlučnosti);

- definisanje pravih rezultata (pri postavljanju očekivanja treba definisati prave rezultate, a ne ispravne korake);

- usmerenost na snage (pogrešno je identifikovati slabosti i pomagati u nadilaženju tih slabosti, već je potrebno istaknuti i usmeriti se na jakost);

- pronaći odgovarajuće radno mesto (pomagati osobi da otkrije kakva treba biti na pravom mestu bolje je nego pomagati joj da bude nagrađena).

Kada zaposleni poseduju vrlo kvalitetne kompetencije, tada je cilj svake organizacije razvijati i zadržati takvog zaposlenog. Kada se govori o zadržavanju talenata veoma je bitan imidž organizacije, jer izgradnja prepoznatljivog imidža poslodavca odnosi se na aktivnosti menadžmenta ljudskih resursa i organizacija radi stvaranja i prenošenja u javnost imidža poželjnog poslodavca i ugodnog mesta za rad koji će privući i zadržati kvalitetne kandidate i talente presudne za ostvarivanje organizacionih ciljeva i postizanje održive konkurentske prednosti.

Troškovi koji se odnose na zaposlene, u smislu njihova napuštanja organizacije kao i naknadno zapošljavanje ili zamena zaposlenih, imaju veliki uticaj na samu organizaciju. Organizacije koje ne uspevaju zadržati svoje zaposlene snose visoke troškove zapošljavanja novih, pada lojalnost njihovih kupaca, a gube i sopstvenu bazu znanja. $\mathrm{Za}$ uspešno privlačenje i zadržavanje zaposlenih organizacije treba da stave naglasak na EVP zaposlenih odnosno treba definisati vrednost ponuđenih zaposlenih.

\section{ISTRAŽIVANJE}

Istraživanje je sprovedeno u periodu od oktobra. do decembra 2020. godine. Ispitanici koji su zaposleni u organizacijama uz saglasnost rukovodilaca, anketirani su $\mathrm{u}$ prostorijama organizacija u vreme kada su ispitanici bili na radnom mestu, a upitnici su administrirani u papirnoj formi. Ukupno je podeljeno 90 upitnika od kojih je vraćeno 77, da bi u istraživanju bilo iskorišćeno 60 odgovora za koje je utvrđeno da su validni. Ovi odgovori bili su potpuni.

\subsection{Predmet istraživanja}

Predmet istraživanja odnosi se na ulogu organizacije $u$ prepoznavanju, razvoju i upravljanju talentima u funkciji što bolje pozicioniranosti organizacije na tržištu.

\subsection{Cilj istraživanja}

Osnovni cilj istraživanja je ispitati kakav uticaj imaju talentovani zaposleni na stvaranje i održavanje konkurentske prednosti organizacije. 


\subsection{Hipoteze istraživanja}

U radu se krenulo od sledećih hipoteza:

- OH. Talenti pedstavljaju konkurentsku prednost organizacije.

- H1. Svaki zaposlen ima jasno definisan plan svog profesionalnog razvoja.

- H2.Postoji razlika kod ispitanika različitog pola u pogledu edukacije i razvoja talenata.

- H3. Postoji razlika kod ispitanika iz IT i sektora prodaje u pogledu razvoja talenata.

\subsection{Uzorak i izvođenje istraživanja}

Uzorak u ovom istraživanju činilo je 60 ispitanika uzorkovanih iz proizvodnog preduzeća koje posluje na teritoriji Vojvodine. Uzorak je činilo 22 muškarca (37\%) 38 žena (63\%).

\subsection{Instrumenti istraživanja}

U istraživanju je korišćen jedan upitnika koji sadrži 28 pitanja. Upitnik se sastoji iz tri dela. Prvi deo upitnika (opšti deo) sadrži 5 pitanja i odnosi se na demografske karakteristike: pol, godine starosti, stručnu spremu, godine radnog staža, kao i na bračni status ispitanika. Drugi deo upitnika se sastoji od 2 pitanja.

U prvom pitanju uspitanik treba da iskaže svoje slaganje ili ne slaganje sa navedenom tvrdnjom, dok drugo pitanje sadrži 5 strategija za razvoj talenada koje treba da rangira prema njihovoj važnosti (1-najmanje važno; 5-najviše važno). Treći deo upitnika se sastoji od 21 i jedne tvrdnje, gde ispitanik treba da zaokruži jedan od pet projeva i time iskaže nivo slaganja sa navedenom tvrdnjom (5-u potpunosti se slažem; 4-u velikoj meri se slažem; 3slažem se; 2-ne slažem se; 1-uopšte se ne slažem.

\subsection{Obrada podataka}

Podaci, koji su dobijeni od ispitanika analizom upitnika koji se bavi temom razvoja talenata kao ključnog faktora stvaranja konkurentske prednosti organizacije, u istraživačkom delu rada su predstavljeni grafički i tabelarno.

Svi podaci analizirani uz pomoć statističkog računarskog programa IBM SPSS.

\section{DISKUSIJA REZULTATA}

Ono što pokreće organizacije prema napred i što doprinosi rastu i razvoju jesu inovacije. Kako se menja okolina tako je potrebno menjati i način poslovanja. A inovacije dolaze od ljudi, prema tome, ono što je zapravo najveće bogatstvo svake organizacije jesu njeni zaposleni. Prilikom promena okoline nespremne organizacije se mogu naći u kritičnim situacijama, a tada do izražaja dolazi potreba za inovacijama.

U svakoj organizaciji kriju se natprosečni zaposleni koji poseduju određeni talent, a taj talent predstavlja "sakriveni dragulj" organizacije. Ono što je glavni izazov danas jeste otkrivanje takvih talenata koji u kritičnim situacijama imaju nove ideje i najčešće ne odustaju od pronalaska rešenja. Talenti nose veliku vrednost, ako se dovoljno dobro brine o njima i ako ih se razvijaju na ispravan način.

Kada su u pitanju polazišta od kojih se krenulo u istraživanju, rezultati su sledeći:

- OH. Talenti predstavljaju konkurentsku prednost organizacije.

Talenti jesu ključni faktor konkurentske prednosti jedne organozacije. Na osnovu rezultata istraživanja možemo zaključiti da su u sva četiri posmatrana sektora talenti značajan faktor, da im se posvećuje pažnja i da je organizacija svesna značajnosti posedovanja talenata $\mathrm{u}$ svom timu. Dakle, OH. se potvrđuje. (Tabela 6. Pitanje: Organizacija ima mogućnost da obezbedi svoje buduče performance kroz ljudse resurse. Rezultati: IT 24,15\%; Knjigovodstvo $7,2 \%$ ，Proizvodnja $10,62 \%$; Prodaja $57,97 \%)$.

Potvrđivanjem ove hipoteze, od koje se i polazi u radu, dolazi se do zaključka da talenti, tj. ljudi, zaista predstavljaju ono najvažnije i najdragocenije što jedna kompanija može da poseduje. Talentovani zaposleni predstavljaju neiscrpan izvor znanja i novih ideja koji jednu organizaciju čine konkurentnijom od drugih.

\section{- H1. Svaki zaposlen ima jasno definisan plan} svog profesionalnog razvoja.

Profesionalni razvoj u osnovi, jeste proces unapređivanja veština i kompetencija sa ciljem unapređenja kvaliteta radnog procesa, kao i učenja/razvoja i postignuća zaposlenih. Osim seminara koji se nude eksterno, značajan deo profesionalnog razvoja pojedinca odvija se u okviru organizacije u kojoj rade. To znači da se profesionalni razvoj ne može svesti na povremene seminare i profesionalna okupljanja. Profesionalni razvoj jeste dugoročan integrativni proces tokom kojeg se, kroz učenje, praktičan rad i istraživačku delatnost, razvijaju i unapređuju znanja, veštine i sposobnosti pojedinca. Prolazeći kroz ovaj proces, zaposleni postaje praktičar koji razmišlja, i u skladu sa svojim potrebama i potrebama preduzeća, postavlja ciljeve vlastitog profesionalnog razvoja.

Primetno je međutim da su u istraživanju prisutna neslaganja u stavovima ispitanika. Jasno je da se prema rezultatima može zaključiti da ni u jednoj oblasti (sektoru) obuhvaćenoj istraživanjem nije potvrđeno da zaposleni imaju jasan plan profesionalnog razvoja. (Tabela 2. Pitanje : Talenti imaju jasno definisane puteve karijere u organizaciji. Rezultati: IT 41,32\%; Knjigovodstvo 12,39\%; Proizvodnja 8,2\%; Prodaja 38,01\%).

Nedefinisan plan profesionalnog razvoja svakog talentovanog pojedinca se može, u ovom slučaju, smatrati nedostatkom. Svaki talenat mora da se neguje i usavršava kako bi mogao da ostvari svoj maksimum, odnosno da iskaže svoj pun potencijal i da na taj načn doprinese konkurentnosti jedne organizacije.

- H2. Postoji razlika kod ispitanika različitog pola u pogledu edukacije i razvoja talenata.

Jasno je iz rezultata ispitivanja, da posmatrani sektori organizacije imaju organizovane obuke i seminare, putem kojih se zaposleni talenti mogu usavršavati. Po pitanju sektora, a gledano i kroz pol, rezultati su jasni i slažu se da ne postoji jasna razlika kod ispitanika različitog pola u pogledu razvoja talenata. Dakle organizacije ne prave 
polnu razliku kada su u pitanju talent i usavršavanje, već se svima daje jednaka šansa. Takođe se i ova hipoteza odbacuje. (Grafikon 6. Pitanje: Talenti učestvuju u pogramima namenjenim razvijanju veština. Rezultati: $M$ $31 \%$; ̌̌ 15\%).

Potvrđivanjem ove hipoteze pokazuje se da ne postoji razlika kod ispitanika različitog pola kada su u pitanju razni oblici edukacije i usavršavanja talenata. $\mathrm{Za}$ jednu organizaciju, koja teži ka tome da bude konkurentna na tržištu rada, veoma je bitno da neguje jednakost među zaposlenima različitog pola i da ne postoji diskriminacija ni u jednom obliku.

- H3. Postoji razlika kod ispitanika iz IT i sektora prodaje u pogledu razvoja talenata.

Prema rezultatima istraživanja, najveću podršku razvoju i usavršavaju iz ispitane grupe daju IT i sektor prodaje. Primetno je da su rezultati kod IT sektora manji, ali je i broj ispitanika obuhvaćen istraživanjem u IT sektoru manji u odnosu na prodaju. U knjigovodstvu i proizvodnji primetni su slabiji rezultati, pa se može konstatovati da postoji značajna razlika kod ispitanika iz različitih oblasti u pogledu razvoja talenata. Samim tim H3. se potvrđuje. (Tabela 5. Pitanje: Talenti, na poslu, mogu učiti mnogo više od onoga što im je dodeljeno kroz radne zadatke. Rezultati: IT 16,66\%; Prodaja 66,66\%).

Analizom rezultata koji potvrđuju ovu hipotezu pokazuje se da organizacija pruža veću podršku IT sektoru kada je usavršavanje u pitanju. Organizacija na taj način pokazuje da više vrednuje digitalizaciju i IT komunikaciju, ali to ne znači da treba da zapostavi ostale sektore, kao što je u ovom slučaju sektor prodaje.

\section{ZAKLJUČAK}

Od trenutka kada organizacija otkrije svoje talente ona već tad mora početi da vodi veću brigu o njima. Time dolazi do upravljanja talentima što je sve potrebniji deo menadžmenta ljudskih potencijala, jer talente nije potrebno samo otkriti, nego i razvijati njihove veštine putem različitih programa obrazovanja i obuke. Još veći izazov leži u zadržavanju talenata unutar organizacije, što nije uvek jednostavno. Organizacija mora paziti da pruži kvalitetne radne uslove i da oblikuje posao na izazovan i prihvatljiv način te da do izražaja dolaze i sistemi motivacije i nagrađivanja, kao jedan od uticajnih činilaca zadržavanja talenata.

Problem s kojim se organizacije takođe suočavaju jeste nedostatak talenata, što zahteva velika ulaganja $u$ pronalaženje talenata $\mathrm{i}$ borbu za talente. Često se spominje rat za talente, ali umesto da se govori o nekoj borbi za njih na tržištu, trebalo bi razviti strategije pomoću kojih bi se novi talenti mogli otkriti i razvijati. Potrebno je stvaranje podsticajnog okruženja u kojem će sami talenti žuditi za svojim razvojem, jer sticanjem novih veština i znanja talent dobija dobar osnov za njegov dalji razvoj i napredak.

Takođe, ne sme se zaboraviti na stvaranje imidža poslodavca i kvalitetne mogućnosti razvoja karijere, jer su i to činioci koji uslovljavaju zadržavanje talenata. Osim navedenog, ono što može biti od velike pomoći kada se talenti otkriju jeste da se pred njih postave pravi rezultati, možda čak da im se dozvoli učestvovanje u postavljanju ciljeva i da to budu ciljevi koji će iz njih izvlačiti pravu snagu koja će ih terati na dalje razvijanje i traženje pravog mesta za njih.

Dakle, na osnovu sprovedenog istraživanja kao i potrvrđene opšte hipoteze od koje se i polazi u radu, a to je da talenti predstavljaju konkurentsku prednost organizacije, može se doći do zaključka da u savremeno doba talenti predstavljaju "suvo zlato" jedne organizacije. Organizacija treba da neguje svoje talente i da neprestano ulažu u njihov razvoj, jer su upravo oni ti koji je na tržištu rada čine konkurentnijom od drugih.

\section{LITERATURA}

${ }^{1}$ Vajiheh, Saadat, (2016), Talent management: the great challenge of leading organizations, International Journal of Organizational Leadership, No. 5. Industrial Management Institut, p.103-109;

${ }^{2}$ Mašić, B. i Đorđević-Boljanović J. (2008) Liderstvo $i$ menadžment znanja u funkciji kreiranja konkurentske prednosti Časopis Lider-Direktor, broj 7, godina II, septembar/oktobar, str. 35-44;

${ }^{3}$ I. Katić, N. Penezić, A. Ivanišević: Upravljanje talentima u savremenoj organizaciji, Poslovna ekonomija Business Economics, Godina X, Pregledni rad Broj II, Str 140-162; 4 Đorđević-Boljanović J, Pavić S.Ž. (2011) Osnove menadžmenta ljudskih resursa, Univerzitet Singidum,Beograd;

5 Buckingham, M. i Coffman, C. (2004.) Što najbolji svjetski menadžeri rade drukčije - prvo odbacite sva pravila. Zagreb: MASMEDIA d.o.o.

6 Bahtijarević-Šiber, F. (2014.) Strateški menadžment ljudskih potencijala: Suvremeni trendovi i izazovi. Zagreb: Školska knjiga,str 171;

7 Pološki Vokić N., Zaninović M., (2010), Analiza čimbenika fluktuacije hrvatskih zaposlenika i njihova usporedba s čimbenicima fluktuacije u najrazvijenijim zemljama svijeta, Zbornik Ekonomskog fakulteta $\mathrm{u}$ Zagrebu, Vol. 8, No.2, pp. 25-36;

\section{Kratka biografija:}

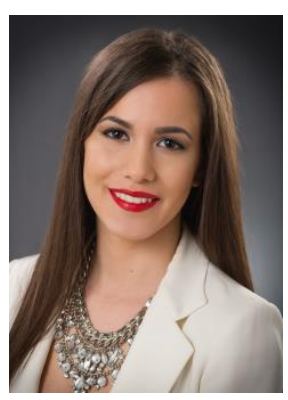

Marija Đurić rođena je u Novom Sadu 1997.god. Diplomske studije završila je na Fakultetu tehničkih nauka u Novom Sadu 2019.god. i stekla je zvanje Diplomirani inženjer menadžmenta ljudskih resursa. Master rad na Fakultetu tehničkih nauka iz oblasti Industrijskog inženjerstva i inženjerskog menadžmenta Menadžment ljudskih resursa odbranila je 2021.god. kontakt: djuricmarija7@gmail.com 